\title{
Management of Black Mold of Onion [Aspergillus niger (Van Teigh)] by using Various Fungicides
}

\author{
R. Saranya*, V.B. Anadani, L.F. Akbari and M. Vanthana \\ Department of Plant Pathology, College of Agriculture, Junagadh, Junagadh Agricultural \\ University, Junagadh-362 001, Gujarat, India \\ *Corresponding author
}

\begin{abstract}
A B S T R A C T
Keywords

Onion, Black mold, Fungicide, Seed treatment, Pot trail.

Article Info

Accepted:

22 February 2017

Available Online:

10 March 2017

In onion, among the postharvest diseases, black mold rot caused by Aspergillus niger is the predominant one. The pathogen is transmitted by contaminated seed or soil. The infection usually begins at germination of onion seeds and may continue throughout storage. The purpose of the study was to explore the control of black mold of onion with various systemic, non systemic and combination of fungicides by treating the seeds. Considering per cent reduction of radial growth of Aspergillus niger, non systemic fungicide dinocap (90.28) and thiram (80.28), systemic fungicide carbendazim (100) and tebuconazole (100), and combination of fungicides tebuconazole + trifioxystrobin (100) and pyraclostrobin + epoxyconazole (100) were recommended to use in pot trail. Out of these six different fungicides tebuconazole + trifioxystrobin treated seeds gave minimum per cent mortality 23.33 and maximum per cent germination 83.33 and vigour index 1091.62, respectively under pot trail.
\end{abstract}

\section{Introduction}

China is the leading producer of onion constituting about 27 per cent of the world total production followed by India constituting about 20 per cent. India is the second largest producer in the world with an area of 12.03 lakh ha and production of 194.01 lakh tons and productivity of 16.1 MT/ha (Anonymous, 2014). Top ten countries including China and India, (mostly Asian countries) constitute more than 60 per cent of the total world production.

In India onion is grown under three crop seasons i.e., kharif, late kharif and rabi. Main crop is in rabi (60\%) and $20 \%$ each is in kharif and late kharif. During 2014, total area under onion was over 12.03 lakh hectares with total production of 194.01 lakh tons (Anonymous, 2014). The productivity in late kharif and rabi is around 25 tons per hectare, whereas in kharif season it is 8-10 tons per hectare. Cloudy weather and constant drizzling during kharif season favour diseases like anthracnose and bulb rotting leading to low productivity, this disease caused huge monitory loss to the growers.

Onion black mold rot disease is the most destructive disease of storages and in the field (Wani and Taskeen, 2011). Rajam (1992) reported that among the postharvest diseases of onion, black mold rot caused by 
Aspergillus niger was the predominant one. The pathogen is transmitted by contaminated seed or soil. The infection usually begins at germination of onion seeds and may continue throughout storage (Hayden and Maude, 1992; Hayden et al., 1994a, b; Koycu and Ozer, 1997; Sirois et al., 1998). Visual symptoms are not observed on sets developing from seeds infected with pathogen because of latent infection (Ozer and Koycu, 1997), although visible external and internal symptoms of black mold occur on infected marketable bulbs (Sumner, 1995; Sinclair and Letham, 1996). Quadri et al., (1982) revealed that the spoilage caused by $A$. niger was as high as 80 per cent. A. niger a soil saprophyte being ubiquitous in occurrence attacks onion by producing various enzymes and toxins and establishes itself in bulb and other tissues. In the present investigation an attempt was made to evaluate different fungicides as seed treatment against black mold of onion.

\section{Materials and Methods}

\section{In vitro evaluation of different fungicides against black mold fungi of onion}

Different fungicides viz., systemic, nonsystemic, and combinations were tested for their effect on growth of Aspergillus niger using poisoned food technique (Sinclair and Dhingra, 1985). The technique involves cultivation of test organism on a medium containing the test chemical. In all experiments Richards medium in which potassium nitrate substituted by ammonium sulphate was used as basal medium to inhibit the sporulation. Per cent growth inhibition of test fungus was calculated by following formula:

$$
\mathrm{I}=\frac{\mathrm{C}-\mathrm{T}}{\mathrm{C}} \times 100
$$

Where, $\mathrm{I}=$ Per cent growth inhibition index $\mathrm{C}=$ Area of test fungus in control $(\mathrm{mm})$

$\mathrm{T}=$ Area of test fungus in respective treatment (mm)

Totally 18 fungicides were tested in three groups viz., systemic, non-systemic, and combination products.

Evaluation of systemic, non-systemic fungicides and their combination against black mold of onion under pot culture

Six different selected fungicides (Table 1) from systemic, non-systemic, and combinations were evaluated for their effect on per cent germination, per cent mortality, root length, shoot length and vigour index of onion seeds, while seeds inoculated with pathogenic Aspergillus niger used as control under pot culture.

Onion seeds of Talaja red variety were surface sterilized with $0.1 \%$ mercuric chloride solution for 2 minutes and subsequently washed with sterile distilled water. Excess water was decanted from the seeds. The spore suspension was prepared from spores taken from the 7 days old culture of the fungus grown on PDA medium. The surface sterilized seeds were artificially inoculated with $A$. niger by soaking in spore suspension for 30 minutes and treated separately by selected fungicides. Inoculated untreated seeds were used as control. Ten seeds were placed at an equal distance in each pots. Observations on seed germination, per cent mortality and root/ shoot length were recorded on $15^{\text {th }}$ day of sowing, respectively. Seedling vigour was also calculated by following formula suggested by Abdul-Baki and Anderson (1973).

Vigour index $=$ Germination \% $\mathrm{x}$ [Root length + Shoot length $(\mathrm{cm})]$ 


\section{Results and Discussion}

Effect of different fungicides against $A$. niger of onion under in vitro condition

The relative efficacy of six different non systemic fungicides was tested at 1500, 2000 and $2500 \mathrm{ppm}$ concentrations. The observations regarding per cent inhibition of linear growth of mycelium are presented in table 2. The perusal of data make it clear that all the non systemic fungicides were effective and gave more than 40 per cent growth inhibition of test fungus at $1500 \mathrm{ppm}$ concentration as compared to control. The most and least effective fungicides were dinocap and copper hydroxide, with a mean inhibition of fungal growth of 90.28 and 54.16 per cent, respectively. The next best fungicide was thiram, which exhibited mean inhibition of 80.28 per cent within the treatments. Maximum toxicity index was observed in dinocap (270.83) followed by thiram (240.85) based on maximum toxicity index of (300.00). Within the fungicides, all three levels of different concentrations significantly differed from each other. Highest concentration (2500 ppm) of all fungicides tested significantly inhibited the fungal growth than lower concentrations of $1500 \mathrm{ppm}$ and $2000 \mathrm{ppm}$. Hayden and Maude (1992) found that thiram as the most effective non systemic fungicide against onion black mold rot caused by Aspergillus niger in agar medium.

The relative efficacy of six different systemic fungicides was tested at 100, 250 and 250 ppm concentrations. The observations regarding per cent inhibition of linear growth are presented in table 3. Different fungicides greatly varied in their efficacy to inhibit the growth of fungus under study. Tebuconazole and carbendazim executed 100 per cent inhibition at all concentration and its mean inhibition was recorded cent per cent. While hexaconazole executed 100 per cent inhibition at 250 and $500 \mathrm{ppm}$ concentration and act as fungistatic and its mean inhibition was recorded 94.31 per cent. Thiophanate methyl gave least mean inhibition of 33.61 per cent. The growth inhibition of test fungus was increased with increase in their concentration. But propiconazole was at par in all three concentration levels. Maximum toxicity index 300.00 was recorded in carbendazim and tebuconazole, followed by 282.93 in hexaconazole on the basis of maximum toxicity index of 300.00 . The least toxicity index 154.59 was noted in thiophanate methyl. Wani and Taskeen (2011) observed that amongst systemic fungicides, carbendazim brought about highest reduction of onion black mold rot, followed by hexaconozole at 2000, 1500, 500 and 125 ppm concentration. Nandeesha et al., (2013) reported that systemic fungicides viz., carbendazim, propiconazole, tebuconazole and hexaconazole were highly effective and completely inhibited the mycelia growth of the pathogen Aspergillus niger causing collar rot in groundnut even at $250 \mathrm{ppm}$ concentraion.

The data on the relative efficacy of six different combination products of fungicides revealed that all the fungicides were capable of inhibiting the growth of $A$. niger at various concentrations as compare to control. The observations regarding per cent inhibition of linear growth are presented in table 4. It is inferred from results that the tebuconazole $55 \%$ EC + trifioxystrobin 25\% WG, pyraclostrobin $13.3 \% \mathrm{WP}+$ epoxyconazole $5 \%$ WP proved to be the most effective in inhibiting growth of the test fungus $(100 \%)$ even at lowest concentration (500 ppm). Cymoxanil 8\% WP + mancozeb 64\% WP also gave cent per cent inhibition of fungus at $1500 \mathrm{ppm}$ concentration with mean inhibition of $(92.60 \%)$ and that combination act as fungistatic. The next best combinations was 
metiram 55\% WG + pyraclostrobin 5\% WG with mean inhibition of $91.95 \%$ which was at par with cymoxanil $8 \% \mathrm{WP}+$ mancozeb $64 \%$ WP. However, zineb $68 \%$ WP + hexaconazole 4\% WP was found poor as compared to other fungicides tested and gave 66.88 per cent growth inhibition of test fungus. The per cent growth inhibition positively correlated with increase in concentration for all the chemicals tested. However, the fungicide metiram 55\% WG + pyraclostrobin $5 \% \mathrm{WG}$ was equally effective at all three concentrations viz., 500, 1000 and $1500 \mathrm{ppm}$. Whereas cymoxanil 8\% WP + mancozeb 64\% WP was equally effective at 500 and $1000 \mathrm{ppm}$ concentrations. Maximum toxicity index was observed in tebuconazole $55 \%$ EC + trifioxystrobin 25\% WG and pyraclostrobin $13.3 \% \mathrm{WP}+$ epoxyconazole $5 \% \mathrm{WP}$ on the basis of maximum toxicity index of (300.00). The least toxicity index (199.41) was noted in zineb 68\% WP + hexaconazole $4 \%$ WP. Nathawat and Mahendra (2014) recorded that combination product of carbendazim + mancozeb and captan $(1500,2000$, and $2500 \mathrm{ppm})$ which were inhibited cent per cent growth of groundnut collar rot fungus Aspergillus niger.

Table.1 List of different fungicides tested under pot trail

\begin{tabular}{|c|l|c|}
\hline S.No & \multicolumn{1}{|c|}{ Treatment } & Dosage per kg of seed \\
\hline 1 & Dinocap 48\% EC & $2 \mathrm{ml}$ \\
\hline 2 & Thiram 75\% WP & $4 \mathrm{~g}$ \\
\hline 3 & Carbendazim 50\% WP & $2 \mathrm{~g}$ \\
\hline 4 & Tebuconazole 25.9\% EC & $1.5 \mathrm{ml}$ \\
\hline 5 & Tebuconazole 5.5\% EC+Trifloxystrobin 25\% WG & $2 \mathrm{~g}$ \\
\hline 6 & Pyraclostrobin 13.3\% WP+Epoxyconazole 5\%WP & $2 \mathrm{~g}$ \\
\hline 7 & Control & \\
\hline
\end{tabular}

Table.2 Effect of different non systemic fungicides on growth inhibition of A. niger

\begin{tabular}{|c|c|c|c|c|c|c|}
\hline \multirow[t]{2}{*}{$\begin{array}{l}\text { Sr. } \\
\text { No. }\end{array}$} & \multirow[t]{2}{*}{ Technical/active Ingredient } & \multicolumn{3}{|c|}{$\begin{array}{l}\text { Concentration in }(\mathrm{ppm}) / \text { per } \\
\text { cent inhibition }\end{array}$} & \multirow[t]{2}{*}{ Mean } & \multirow[t]{2}{*}{$\begin{array}{l}\text { Toxicity } \\
\text { Index }\end{array}$} \\
\hline & & 1500 & 2000 & 2500 & & \\
\hline 1 & Copper hydroxide 77\%WP & 43.22 & 46.35 & 72.91 & 54.16 & 162.48 \\
\hline 2 & Copper oxychloride 50\%WP & 41.92 & 59.11 & 86.19 & 62.41 & 187.22 \\
\hline 3 & Mancozeb 75\% WP & 40.88 & 69.01 & 79.94 & 63.28 & 189.83 \\
\hline 4 & Chlorothalonil 75\% WP & 58.17 & 67.44 & 77.86 & 67.82 & 203.47 \\
\hline 5 & Thiram 75\%WP & 72.90 & 80.72 & 87.23 & 80.28 & 240.85 \\
\hline 6 & Dinocap $48 \%$ EC & 82.55 & 88.28 & 100 & 90.28 & 270.83 \\
\hline \multirow[t]{6}{*}{7} & Control & - & - & - & - & - \\
\hline & Mean & 56.61 & 68.49 & 84.02 & - & - \\
\hline & & \multicolumn{2}{|c|}{ Fungicide $(\mathrm{F})$} & \multicolumn{2}{|c|}{ Concentration $(\mathrm{C})$} & $\mathrm{F} \times \mathrm{C}$ \\
\hline & S.Em. \pm & \multicolumn{2}{|c|}{0.84} & \multicolumn{2}{|c|}{0.55} & 1.45 \\
\hline & C.D. at $5 \%$ & \multicolumn{2}{|c|}{2.40} & \multicolumn{2}{|c|}{1.57} & 4.16 \\
\hline & C.V.\% & \multicolumn{2}{|c|}{4.22} & & & \\
\hline
\end{tabular}


Table.3 Effect of different systemic fungicides on growth inhibition of A. niger

\begin{tabular}{|c|c|c|c|c|c|c|}
\hline \multirow[t]{2}{*}{$\begin{array}{l}\text { Sr. } \\
\text { No. }\end{array}$} & \multirow[t]{2}{*}{ Technical/active Ingredient } & \multicolumn{3}{|c|}{$\begin{array}{l}\text { Concentration in }(\mathbf{p p m}) / \\
\text { per cent inhibition }\end{array}$} & \multirow[t]{2}{*}{ Mean } & \multirow[t]{2}{*}{$\begin{array}{l}\text { Toxicit } \\
\text { y Index }\end{array}$} \\
\hline & & 100 & 250 & 500 & & \\
\hline 1 & Carbendazim 50\%WP & 100 & 100 & 100 & 100 & 300 \\
\hline 2 & Tebuconazole $25.9 \%$ EC & 100 & 100 & 100 & 100 & 300 \\
\hline 3 & Hexaconazole 5\% EC & 82.93 & 100 & 100 & 94.31 & 282.93 \\
\hline 4 & Thiophanate methyl 70\% WP & 20.05 & 33.37 & 47.40 & 33.61 & 100.82 \\
\hline 5 & Fosityle - AL 80\% WP & 36.18 & 48.57 & 69.84 & 51.53 & 154.59 \\
\hline 6 & Propiconazol 25\% EC & 84.57 & 85.50 & 88.54 & 86.20 & 258.60 \\
\hline \multirow[t]{6}{*}{7} & Control & - & - & - & - & - \\
\hline & Mean & 70.62 & 77.91 & 84.30 & - & - \\
\hline & & \multicolumn{2}{|c|}{ Fungicide $(\mathrm{F})$} & \multicolumn{2}{|c|}{ Concentration $(\mathrm{C})$} & $\mathrm{F} \times \mathrm{C}$ \\
\hline & S.Em. \pm & \multicolumn{2}{|c|}{0.67} & \multicolumn{2}{|c|}{0.44} & 1.16 \\
\hline & C.D. at $5 \%$ & \multicolumn{2}{|c|}{1.91} & \multicolumn{2}{|c|}{1.25} & 3.31 \\
\hline & C.V.\% & \multicolumn{2}{|c|}{3.02} & & & \\
\hline
\end{tabular}

Table.4 Effect of different combination of fungicides on growth inhibition of A. niger

\begin{tabular}{|c|c|c|c|c|c|c|}
\hline \multirow[t]{2}{*}{$\begin{array}{l}\text { Sr. } \\
\text { No. }\end{array}$} & \multirow[t]{2}{*}{$\begin{array}{l}\text { Technical/active } \\
\text { Ingredient }\end{array}$} & \multicolumn{3}{|c|}{$\begin{array}{c}\text { Concentration in }(\mathrm{ppm}) / \\
\text { per cent inhibition }\end{array}$} & \multirow[t]{2}{*}{ Mean } & \multirow[t]{2}{*}{$\begin{array}{l}\text { Toxicity } \\
\text { Index }\end{array}$} \\
\hline & & 500 & 1000 & 1500 & & \\
\hline 1 & $\begin{array}{l}\text { Zineb } 68 \% \text { WP }+ \\
\text { Hexaconazole } 4 \% \mathrm{WP} .\end{array}$ & 41.71 & 75.63 & 82.09 & 66.47 & 199.41 \\
\hline 2 & $\begin{array}{l}\text { Iprodine } 25 \% \mathrm{WP}+ \\
\text { Carbendazim 25\% WP. }\end{array}$ & 74.46 & 78.80 & 82.58 & 78.62 & 235.86 \\
\hline 3 & $\begin{array}{l}\text { Cymoxanil 8\% WP + } \\
\text { Mancozeb 64\% WP. }\end{array}$ & 87.92 & 89.88 & 100.00 & 92.60 & 277.80 \\
\hline 4 & $\begin{array}{l}\text { Metiram 55\% WG+ } \\
\text { Pyraclostrobin 5\% WG. }\end{array}$ & 91.17 & 92.17 & 92.50 & 91.95 & 275.85 \\
\hline 5 & $\begin{array}{l}\text { Tebuconazole } 55 \% \mathrm{EC}+ \\
\text { Trifioxystrobin } 25 \% \mathrm{WG}\end{array}$ & 100.00 & 100.00 & 100.00 & 100.00 & 300.00 \\
\hline 6 & $\begin{array}{l}\text { Pyraclostrobin } 13.3 \% \mathrm{WP}+ \\
\text { Epoxyconazole 5\% WP. }\end{array}$ & 100.00 & 100.00 & 100.00 & 100.00 & 300.00 \\
\hline 7 & Control & - & - & - & - & - \\
\hline & Mean & 82.54 & 89.41 & 92.86 & - & - \\
\hline & & \multicolumn{2}{|c|}{ Fungicide $(\mathrm{F})$} & \multicolumn{2}{|c|}{ Concentration (C) } & $\mathrm{F} \times \mathrm{C}$ \\
\hline & S.Em. \pm & \multicolumn{2}{|c|}{0.76} & \multicolumn{2}{|c|}{0.50} & 1.32 \\
\hline & C.D. at $5 \%$ & \multicolumn{2}{|c|}{2.17} & \multicolumn{2}{|c|}{1.42} & 3.76 \\
\hline & C.V.\% & \multicolumn{2}{|c|}{3.01} & & & \\
\hline
\end{tabular}


Table.5 Effect of different fungicides on per cent germination, per cent mortality and vigour index of onion seeds against $A$. niger under pot culture

\begin{tabular}{|c|l|c|c|c|c|c|}
\hline S.No & Treatment & $\begin{array}{c}\text { Percent } \\
\text { germination }\end{array}$ & $\begin{array}{c}\text { Percent } \\
\text { mortality }\end{array}$ & $\begin{array}{c}\text { Root } \\
\text { length } \\
\text { (cm) }\end{array}$ & $\begin{array}{c}\text { Shoot } \\
\text { length } \\
(\mathbf{c m})\end{array}$ & $\begin{array}{c}\text { Vigour } \\
\text { index }\end{array}$ \\
\hline 1 & Dinocap 48\% EC (2m1/kg) & 60.00 & 50.00 & 3.00 & 6.43 & 696.00 \\
\hline 2 & Thiram 75\% WP (4g/kg) & 73.33 & 36.67 & 3.83 & 6.50 & 757.68 \\
\hline 3 & Carbendazim 50\% WP (2g/kg) & 76.67 & 33.33 & 4.20 & 7.03 & 861.25 \\
\hline 4 & Tebuconazole 25.9\% & 83.33 & 26.67 & 4.37 & 7.23 & 966.62 \\
& EC $(1.5 \mathrm{ml} / \mathrm{kg})$ & & & & & \\
\hline 5 & Tebuconazole 5.5\%EC+ & 83.33 & 23.33 & 5.17 & 7.93 & 1091.62 \\
& Trifloxystrobin 25\% WG (2g/kg) & & & & & \\
\hline 6 & Pyraclostrobin 13.3\% WP + & 70.00 & 43.33 & 3.60 & 6.70 & 721.00 \\
& Epoxyconazole 5\%WP (2g/kg) & & & & & \\
\hline 7 & Control & 46.67 & 66.67 & 2.40 & 5.53 & 370.24 \\
\hline & S.Em. + & 3.56 & 3.09 & - & - & 52.94 \\
& C.D. at 5\% & 10.81 & 9.36 & - & - & 160.60 \\
& C.V. \% & 8.76 & 13.36 & - & - & 11.75 \\
\hline
\end{tabular}

Effect of different fungicides as seed dresser against $A$. niger under pot culture

In this study of six different fungicides used as seed dresser, revealed that all the fungicides were found to be most effective against $A$. niger by increasing percentage of seed germination, seeding length and vigour index, respectively with minimum per cent mortality as compared to control. Perusal of data from table 5 revealed that minimum $23.33 \%$ mortality and maximum $83.33 \%$ seed germination, and 1091.62 vigour index, respectively were recorded in seed treatment of tebuconazole $5.5 \%$ EC + trifloxystrobin $25 \% \mathrm{WG}$ as compared to control with $66.67 \%$ mortality, $46.67 \%$ seed germination, and 370.24 vigour index. However, tebuconazole $25.9 \%$ EC was at par with tebuconazole $5.5 \%$ EC + trifloxystrobin $25 \% \mathrm{WG}$ in all aspects viz., per cent germination $(83.33 \%)$, per cent mortality (26.67\%), and vigour index (966.62). Carbendazim 50\% WP and Thiram 75\% WP is also at par with tebuconazole $5.5 \% \mathrm{EC}+$ trifloxystrobin $25 \%$ WG with 76.67 and 73.33 per cent germination, respectively. Dinocap $48 \%$ EC was significantly effective against A.niger in comparison with control however, it was less effective fungicide while comparing with all other fungicides.
Seed treatment with thiram, prochloraz and benomyl + thiram mixture stimulated the rate of germination of onion seed was reported by Ozer and Koycu (1998). Gupta et al., (2012) has already reported that carbendazim (Bavistin) was the best seed dresser against seed borne A. niger followed by thiram in improving seed germination and vigour index of onion. Various workers have also been reported that seeds treated with fungicides significantly increasing the per cent germination and vigour index of seeds by reducing the per cent mortality (Akgul et al., (2011) and Rohats (2014)).

\section{References}

Abdul-Baki, A.A. and Anderson, J.D. 1973. Vigour determination of soybean seeds by multiple criteria. Crop Sci., 13: 630-633.

Akgul, D.S., Ozgonen, H. and Erkilic, A. 2011. The effects of seed treatments with fungicides on stem rot caused by sclerotium rolfsii sacc., in peanut. Pak. J. Botnay, 43(6): 2991-2996.

Anonymous. 2014. Hand Book on Agricultural Statistics. Available at http://agricoop.nic.in/imagedefault/whatsne w/handbook 2014.pdf accessed September, 2015.

Gupta, R., Khokhar, M.K. and Lal, R. 2012. 
Management of the Black Mould Disease of Onion, Plant Pathol. Microbiol., 3(5).

Hayden, N.J. and Maude, R.B. 1992. The role of seed-borne Aspergillus niger in transmission of black mould of onion. Plant Pathol., 41: 573-581.

Hayden, N.J., Maude, R.B., Proctor, F.J. 1994a. Studies on the biology of black mold (Aspergillus niger) on temperate and tropical onions 1. A comparison of sources of the disease in temperate and tropical field crops, Plant Pathol., 43: 562-569.

Hayden, N.J., Maude, R.B., Proctor, F.J. 1994b. Studies on the biology of black mold (Aspergillus niger) on temperate and tropical onions 2. The effect of treatments on the control of seed-borne A. niger. Plant Pathol., 43: 570-578.

Koycu, N.D. and Ozer, N. 1997. Determination of seed borne fungi in onion and their transmission to onion set. Phytoparasitica, 25: 25-31.

Nandeesha, B.S., Kumar, M.R. and Reddy, N.P.K. 2013. Evaluation of different fungicides and their compatibility with potential Trichoderma spp. for the management of Aspergillus niger, incitant of collar rot of groundnut. Asian J. Biol. Life Sci., 2(1): 5963.

Nathawat, B.D.S. and Mahendra, P. 2014. Evaluation of fungicides, botanical and Trichoderma spp. against collar rot of Groundnut (Arachis hypogaea L.) caused by Aspergillus niger van Tiegham. Annals of Plant Protection Sci., 22(2): 382-385.

Ozer, N. and Koycu, N.D. 1998. Evaluation of seed treatments for controlling Aspergillus niger and Fusarium oxysporum on onion seed. Pytopathologica Mediterranea, 37(1): 33-40.

Ozer, N. and Koycu, N.D. 1997. The pathogenicity of Aspergillus niger and some Fusarium species on onion seed and seedlings. In: Proceedings of the 10th Congress of the Mediterranean Phytopathological Union, 1-5 June 1997, Monpellier (France), pp. 277-281.

Quadri, S.M.H., Srivastava, K.J., Bhonde, S. R., Pandey, U.B. and Bhagchandani, P.M. 1982. Fungicidal bioassay against certain important pathogens of onion, Pesticides, 16: 11-16.

Rajam, S.R. 1992. Studies on the post harvest fungal spoilage of onion. M. Sc. Ag.) Thesis (Unpublished), Tamil Nadu Agricultural University, Coimbatore.

Rohtas. 2014. Management of collar rot of groundnut (Arachis hypogaea L.) caused by Aspergillus niger van Teighem. M. Sc. Ag.) Thesis, CCS Haryana Agricultural University, Haryana.

Sinclair, J.B. and Dhingra, O.D. 1985. Basic plant pathology methods, CRC Press, Inc. Corporate Bulding, M. W. Boca Raton, Florida, 232-315.

Sinclair, P.J. and Letham, D.B. 1996. Incidence and sites of visible infection of Aspergillus niger on bulbs of two onion (Allium cepa) cultivars. Australian Plant Pathol., 25: 811.

Sirois, K.L., LoParco, D.P. and Lorbeer, J.W. 1998. Development of a bioassay to determine the presence of specified fungal pathogen of onion. In: Proceedings of the $7^{\text {th }}$ Biennial National Onion (and Other Allium) Research Conference, California, 10-12 December 1998, pp. 231-237.

Sumner, D.R. 1995. Black mold, In: Schwartz, H.F., Mohan, S.K. Eds.), Compendium of Onion and Garlic Diseases. American Phytopathology Society Press, Minnesota, USA, 26-27.

Wani, A.H. and Taskeen. 2011. Management of black mold rot of onion. Mycopathol., 9: 43-49.

\section{How to cite this article:}

Saranya, R., V.B. Anadani, L.F. Akbari and Vanthana, M. 2017. Management of Black Mold of Onion [Aspergillus niger (Van Teigh)] by using Various Fungicides. Int.J.Curr.Microbiol.App.Sci. 6(3): 16211627. doi: https://doi.org/10.20546/ijcmas.2017.603.187 